\section{Sammenheng mellom kronisk stress og Alzheimers sykdom?}

\author{
Økte nivåer av kortikotropinfrigjø- \\ rende faktor i hjernen kan forverre \\ forløpet av Alzheimers sykdom, \\ antydes det i studier med trans- \\ gene mus.
}

Alzheimers sykdom karakteriseres av bl.a. nedslag av $\beta$-amyloidpeptid (A $\beta)$ i amyloide plakk og hyperfosforylert tauprotein i nevrofibrillære floker i hjernen. Det er laget transgene musemodeller av sykdommen, der muterte humangener er introdusert i musegenomet, f.eks. genet for mutert $A \beta$-forløperprotein eller tau.

Ved Alzheimers sykdom er det overaktivitet i hypothalamus-hypofyse-binyre-aksen. Det samme ble funnet i begge musemodellene - akutt stress økte kortikosteroidsekresjonen mye mer enn hos kontrollmusene (1). I en modell for kronisk stress, der musene ble holdt isolert fra andre mus og dessuten hadde hemmet bevegelse $\mathrm{i}$ en måned, økte de histologiske tegn på Alzheimers sykdom i musehjernen, og rom- og frykthukommelsen var svekket. Stressvirkningene lot seg ikke reprodusere av kronisk kortikosteroidmedisinering. Men hemming av en reseptor for kortikotropinfrigjørende faktor motvirket akselerasjonen av demensforandringene hos musene. En tredje transgen musestamme, som hadde overproduksjon av kortikotropinfrigjørende faktor, hadde også økt hyperfosforylert tau.

- Disse musemodellfunnene kan vise vei mot nye behandlingsprinsipper, sier professor Tormod Fladby ved Akershus universitetssykehus. - Økt taufosforylering kan gi redusert effektivitet av rask aksonal transport, akkumulasjon av $\mathrm{A} \beta$-forløperprotein i endoplasmatisk retikulum og økt forekomst av skadelige $A \beta$-metabolitter - med endret transkripsjon til følge. Denne typen funn relaterer dermed til sentrale patologiske komponenter i utviklingen av Alzheimers sykdom og til potensielt påvirkbare stressrelaterte faktorer. Men mye arbeid gjenstår, bl.a. grundigere dokumentasjon av relevans for human sykdomsutvikling, sier Fladby.

\section{Haakon B. Benestad}

h.b.benestad@medisin.uio.no

Universitetet i Oslo

\section{Litteratur \\ 1. Carroll JC, Iba M, Bangasser DA et al. Chronic stress exacerbates tau pathology, neurodegenera- tion, and cognitive performance through a cortico- tropin-releasing factor receptor-dependent mechanism in a transgenic mouse model of tauo- pathy. J Neurosci 2011: 31: 14436-49.}

\section{Nytt alternativ til warfarin}

\author{
Nye antikoagulantia vil etter hvert \\ erstatte warfarin ved atrieflimmer
}

Warfarin ved atrieflimmer har en veldokumentert forebyggende effekt mot hjerneslag. Gode alternativer har vært etterlyst pga. den upraktiske oppfølgingen, blødningsrisikoen og faren for interaksjoner med andre legemidler. I en randomisert studie har man sammenliknet koagulasjonsfaktor Xa-hemmeren rivaroksaban $20 \mathrm{mg}$ én gang daglig med warfarin hos pasienter med atrieflimmer (1). Studien omfattet 14200 pasienter med 3,5 i gjennomsnittlig $\mathrm{CHADS}_{2}$-skår.

I warfaringruppen var årlig forekomst av hjerneslag eller systemiske embolier 2,4\%, mot $2,1 \%$ i rivaroksabanguppen. En jevnlikhetsanalyse (non-inferior) viste en signifikant forskjell mellom rivaroksaban og warfarin $(\mathrm{p}<0,001)$, mens dette ikke var tilfellet etter behandlingsintensjonsprinsippet (intention to treat; $p=0,12$ ) Klinisk relevante blødninger forekom like hyppig, men det var signifikant færre hjerneblødninger $(0,5 \%$ mot $0,7 \%)$ og fatale blødninger $(0,2 \%$ mot $0,5 \%)$ blant dem som fikk rivaroksaban.

- Studien ble presentert på en kardiologikongress i USA i 2010 og er spesielt viktig pga. den lavere risikoen for hjerneblødning, sier overlege Jan Pål Loennechen ved Klinikk for hjertemedisin, St. Olavs hospital. - Resultatene sammenfaller med resultatene $\mathrm{i}$ tre andre studier av faktor Xa-hemmerne rivaroksaban og apixaban og trombinhemmeren dabigatran, som alle er interessante altenativer til warfarin. De ulike studiene kan ikke sammenliknes direkte, så det er vanskelig å si hvilket medikament som er best. Med mindre det opptrer uventede alvorlige bivirkninger, vil de nye medikamentene gradvis overta for warfarin ved atrieflimmer.

Viktige innvendinger er høy pris og mangel på gode antidoter. De nye antikoagulantia bør ikke tas i bruk ved andre tilstander der samme klare dokumentasjon mangler, sier Loennechen.

\section{Geir Jacobsen}

geir.jacobsen@ntnu.no

Tidsskriftet

\footnotetext{
Litteratur

1. Patel MR, Mahaffey KW, Garg J et al. Rivaroxaban versus warfarin in nonvalvular atrial fibrillation. N Engl J Med 2011; 365: 883-91.
} i genitale slimhinner. Disse blødningene er en mulig mekanisme som gir økt hivsmitte. Videre induserer schistosomaegg aktivering av inflammatoriske celler i slimhinnen, inklu-

\section{Øyunn Holen}

Mikrobiologisk avdeling

Bærum sykehus

\section{Litteratur}

1. Mbabazi PS, Andan O, Fitzgerald DW et al. Examining the relationship between urogenital schistosomiasis and HIV infection. PLoS Negl Trop Dis 2011; 5: e1396. 